\title{
The Implementation of TQM in R\&D Environments
}

\author{
Barbara Bigliardi', Francesco Galati²
}

\begin{abstract}
Research \& development has been identified as a key element to achieve competitive advantage, particularly in contexts of change and especially for technology-based companies. Nowadays, organizations are aware that quality, and quality management as a consequence, represents an important strategic stimulus, thus assuming a fundamental role in the business strategies implementation. This article, aiming at outlining the practices that managers believe are critical for achieving quality management in applied research and development, examines the adoption of total quality management within R\&D based organizations, and its impact in terms of performance. This is a qualitative research from a multicase study on eleven companies. Data were collected through open interviews, using a semi-structured script, with R\&D managers and employees from each company. Our study supports the hypothesis that TQM practices positively impact the performance of an organization. Implications for managers and for academics can be derived from the study.
\end{abstract}

Keywords: TQM; R\&D; performance; multicase. 


\section{Introduction}

Total Quality Management (TQM) is a management philosophy aimed at the continuous improvement of the quality of products and processes, with the final aim to meet customers' needs (Ahire et al., 1995). As introduced by Deming (1986), "TQM makes use of a particular set of principles, practices and techniques to expand business and profits that provides a bypass to enhanced productivity by avoiding reworks, rejects, waste, customer complaints and high costs". This issue has received great attention from both managers and researchers during the last two decades, as demonstrated by the proliferation of studies on this matter. It is evident from empirical studies that TQM positively impact on the performance of those organizations that implement its practices and principles (e.g., Prajogo and Hong, 2008; Taddese and Osada, 20I0; Hassan et al., 20I2). Among others, some of the proven benefits of TQM implementation listed by the majority of works are improved quality, improved customer satisfaction, reduced cost, efficient delivery of products and services, and higher performance (Kiella and Golhar, 1997; Kumar and Boyle, 200I; Prajogo and Hong, 2008).

TQM practices may differ from country to country, as well as from company to company. In particular, as far as the company level is considered, numerous example of implementation of TQM is available in literature regarding wider functions in organizations, but only a few refers to TQM application in the research and development (R\&D) (Prajogo and Hong, 2008). Thus, the aim of our study is to fill this gap using data from R\&D divisions of firms in Italy.

Following a twofold methodology, that is literature review and case study, this paper aims at outlining the practices that managers believe are critical for achieving quality management in applied research and development, thus examining the adoption of TQM within R\&D based organizations, and its impact in terms of performance. The paper is structured as follows: as first, we present a literature review on TQM issues, both in general and in R\&D environments. Then, the methodology adopted is described, together with a description of the sample of companies investigated. It is followed by the results section. Discussion and future research conclude the paper, together with a discussion of limitation of the study itself.

\section{TQM: evidence from the literature}

TQM has received great attention both from managers and academics, as the proliferation of papers dealing on this issue demonstrates. The analysis of the extant literature allows to identify two main areas of interests: on the one hand, studies dealing with formal quality award models, and on the other hand studies dealing with measurement and practices of TQM.As for the former, the main models that have been investigated have been, among others: the Deming Prize, the European Quality Award and the Malcolm Baldrige National Quality Award (Lee et al., 2003). As for the latter, numerous practices have been proposed, investigated and empirically analyzed in literature.

Specifically, numerous research studies have dealt on such issue and some of them have reviewed the extant literature (e.g., Sila and Ebrahimpour, 2002; Sharma, 2006), thus providing an ample discussion on the main TQM practices. Almost all these studies, in particular, proposed a series of factors, and not a single one, that are critical for TQM.Among these factors, those that received great attention from researchers are listed in Table I. The same table also reports the references of the studies that proposed each single factor.

Other factors emerged from the literature, but they have received lower attention by researchers, such as benchmarking (Lu and Sohal, 1993; Powell, 1995), incentive and recognition system process (Talavera, 2004; Hassan et al., 2012), product and service design (Saraph et al., 1989; Flyyn et al., 1994), role of quality department (Saraph et al., 1989).

In addition to these factors, great attention has been paid also to the impact of TQM on business performance. Specifically, scholars have referred to different performance types, such as financial (Agus and Hassan, 2000), organizational (Sterman et al., 1997), business (Easton and Jarrell, 1994; Brah et al., 2000), innovative (Bigliardi, 2013), operational (Terziovski and Samson, 1999) and quality (Zehir et al., 2012). For example, different studies (e.g., Brah et al., 2002; Kaynak, 2003; Prajogo and Sohal, 2003; Prajogo, 2005; Zehir et al., 20I2) have proven that TQM implementation has strong and positive relations with quality performance. Similarly, Kumar et al. (2009) found in their studies that an improvement in process, product and service quality resulted from the implementation of TQM practices.As far as business performance are concerned, Gadenne and Sharma (2002), Lagroesen and Lagroesen (2003) as well as Hassan et al. (20I2) showed that TQM positively impact on business performance. Finally, both the works by Malik et al. (2008) and Hassan et al. (20I2), provided evidences of the positive correlation existing between TQM and Organizational performance.

As listed above, examples of applications of TQM practices are available within a series of industries: manufacturing (Fotopoulos and Psomas, 2009; Hassan et al., 20I2), health care (Kaplan et al., 20I0), service (Feng et al., 2008), etc...Although continuous attention is given to TQM within different industrial sectors, it is only in the last decade that researchers have started to investigate this issue within a particular company's unit, that is the R\&D (among others, Kumar and Boyle, 200I; Petroni et al., 2003; Prajogo and Hong, 2008). 


\begin{tabular}{|c|c|}
\hline TQM factors & Main references \\
\hline Continuous improvement & $\begin{array}{l}\text { Talavera (2004); Sharma and Kodali (2008); Hassan et al. } \\
\text { (20I2); Zehir et al.(20I2) }\end{array}$ \\
\hline Customer focus & $\begin{array}{l}\text { Flyyn et al. (1994); Powell (1995); Rahman (200I); Brah et al. } \\
\text { (2002); Prajogo and Sohal (2003); Wali et al. (2003); Talavera } \\
\text { (2004); Prajogo (2005); Sila (2005); Karuppusami and Gand- } \\
\text { hinathan (2006); Tari et al. (2006); Fryer et al. (2007); Sila } \\
\text { (2007); Sharma and Kodali (2008); Hassan et al. (20I2); Zehir } \\
\text { et al. (20I2) }\end{array}$ \\
\hline Employees empowerment and involvement & $\begin{array}{l}\text { Flyyn et al. (1994); Powell (1995); Wali et al. (2003); Talavera } \\
\text { (2004); Karuppusami and Gandhinathan (2006); Hassan et al. } \\
\text { (2012); Zehir et al. (2012) }\end{array}$ \\
\hline Education and training & Saraph et al. (1989); Lu and Sohal (I993); Powell (1995) \\
\hline Process management & $\begin{array}{l}\text { Saraph et al. (1989); Lu and Sohal (I993); Flyyn et al. (I994); } \\
\text { Powell (1995); Rahman (200I); Brah et al. (2002); Prajogo } \\
\text { and Sohal (2003);Wali et al. (2003); Prajogo (2005); Sila } \\
\text { (2005); Karuppusami and Gandhinathan (2006); Tari et al. } \\
\text { (2006); Sila (2007); Sharma and Kodali (2008); Zehir et al. } \\
\text { (20I2) }\end{array}$ \\
\hline Quality data and reporting & $\begin{array}{l}\text { Saraph et al. (1989); Lu and Sohal (1993); Flyyn et al. (1994); } \\
\text { Wali et al. (2003) }\end{array}$ \\
\hline Quality management (strategic and design) & Lu and Sohal (1993); Hassan et al. (20I2) \\
\hline Supplier quality management and involvement & $\begin{array}{l}\text { Flyyn et al. (1994); Powell (1995); Brah et al. (2002); Sila } \\
\text { (2005); Karuppusami and Gandhinathan (2006); Sila (2007); } \\
\text { Fryer et al. (2007); Macinati (2008); Sharma and Kodali } \\
\text { (2008); Zehir et al. (20I2) }\end{array}$ \\
\hline Teamwork & Sila (2005); Tari et al. (2006); Sila (2007) \\
\hline Top management involvement and leadership & $\begin{array}{l}\text { Saraph et al. (1989); Lu and Sohal (I993); Flyyn et al. (I994); } \\
\text { Powell (1995); Rahman (200I);Wali et al. (200I); Brah et al. } \\
\text { (2002); Prajogo and Sohal (2003);Wali et al. (2003); Talavera } \\
\text { (2004); Prajogo (2005); Sila (2005); Karuppusami and Gand- } \\
\text { hinathan (2006); Tari et al. (2006); Fryer et al. (2007); Sila } \\
\text { (2007); Macinati (2008); Sharma and Kodali (2008);Malik and } \\
\text { Khan (20I I); Hassan et al. (20I2); Zehir et al. (20I2) }\end{array}$ \\
\hline
\end{tabular}

Table I:TQM factors proposed in literature.

This is mainly due to the fact that, as some authors stressed, TQM and R\&D are based on different and often contradictory pillars (Sharman, 1996).

\section{TQM and R\&D}

As stated above, the TQM practices that are successful in manufacturing environments are widely published and thus well known. But, as stressed also by Kumar and Boyle (200I), "the same practices when applied in R\&D environments may prove disastrous". Thus, TQM practices specific for the R\&D have to be identified. When reviewing the extant literature on TQM in R\&D, it stands out that a generally ac- cepted definition of quality in R\&D does not exist. In particular, several authors agree in stating the difficulty for $R \& D$ based companies to achieve the goals of quality mainly due to the low tangibility and repetition of R\&D activities, the lack of R\&D quality measurements and a lack of employees' commitment regarding quality (Tenner, 1991; Patino, 1997; Chang and Hsu, 1998).

None of the pioneering researcher of TQM such as Deming, Juran, or Crosby, has specifically addressed the role of R\&D in quality management. The recent literature, however, shows a number of empirical and case studies supporting the applicability of TQM to R\&D environment (Taylor and 
Pearson, 1994; Pearson et al., 1998; Samson and Terziovski, 1999; Kumar and Boyle, 200I; Ojanen et al., 2002; Prajogo and Sohal, 2003; Prajogo and Hong, 2008), providing evidences that TQM is beneficial for R\&D (Chatterji and Davidson, 200I). Similarly, several attempts are available in literature providing both models of implementation of TQM in R\&D environments, and TQM practices specific for the R\&D. As for the former, Pearson et al. (1998) proposed a fourphased model to implement quality in R\&D, that is: initiation, involvement, implementation and sustenance. Similarly, Kumar and Boyle (200I), proposed implementing R\&D strategic management, $R \& D$ quality awareness and $R \& D$ process management practices as the way to correctly implement TQM in R\&D environments. As far as the TQM practices for $R \& D$ are concerned, as a consequence of the difficulty in adopting the same manufacturing TQM practices, TQM practices adapted for the R\&D environment have to be identified. Several works available in literature provided a lists of practices suitable for the R\&D environments. These are listed, for the sake of brevity, in the following Table 2, together with the main references and the number of factors that have been proposed.

On the basis of these premises, the aim of our paper can be translated into two main research questions:

I) Does the implementation of TQM practices in R\&D environments affect the business performance?

2) Which TQM practices in R\&D environments are critical for an effective implementation of this approach?

\begin{tabular}{|c|c|c|}
\hline Authors & $\begin{array}{c}\text { Number } \\
\text { of } \\
\text { factors }\end{array}$ & TQM factors and practices \\
\hline $\begin{array}{l}\text { Samson and } \\
\text { Terziovski } \\
\text { (1999) }\end{array}$ & 6 & 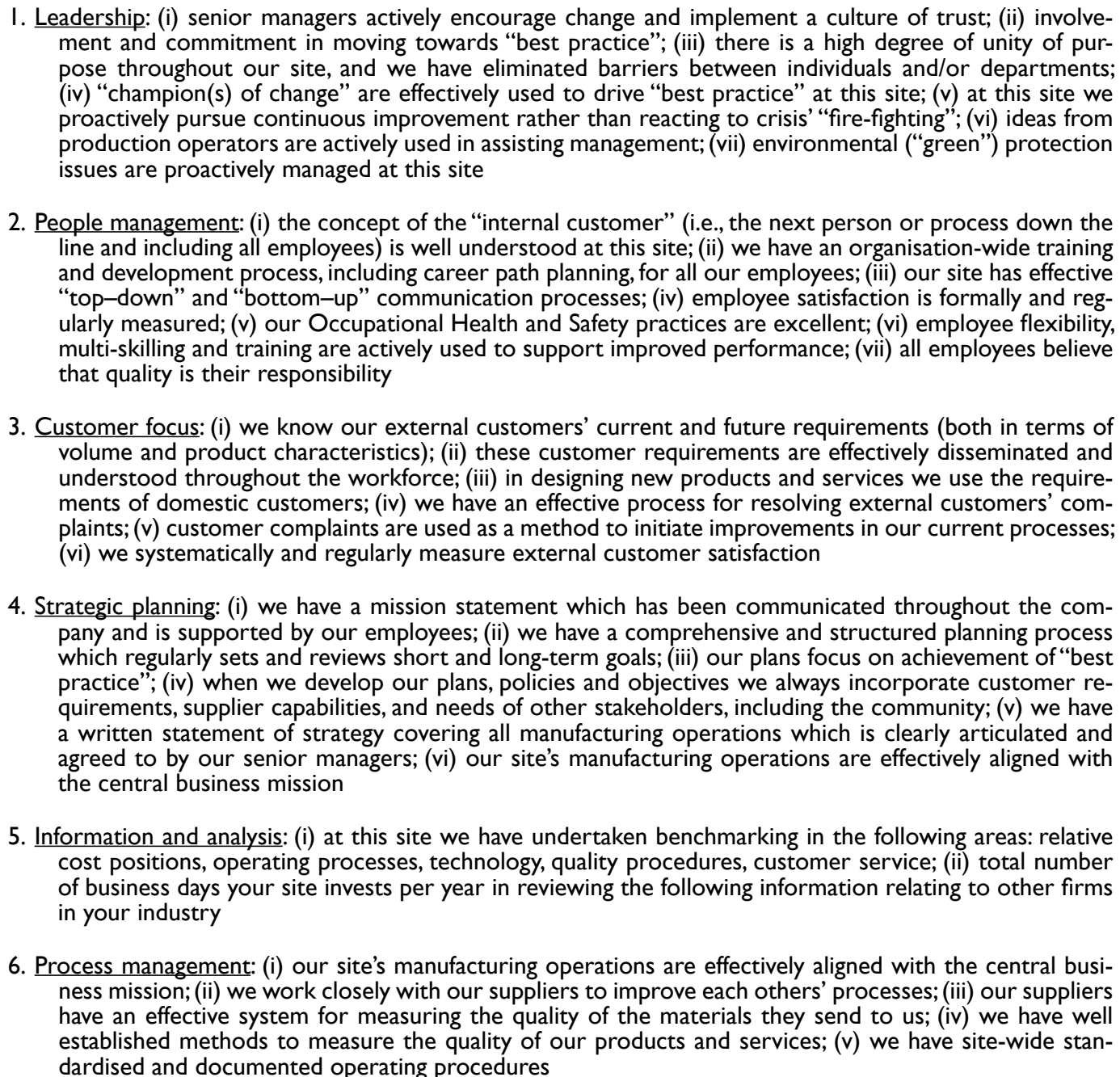 \\
\hline
\end{tabular}

ISSN: 07 I8-2724. (http://www.jotmi.org) 


\begin{tabular}{|c|c|c|}
\hline $\begin{array}{l}\text { Kumar } \\
\text { and Boyle } \\
(2001)\end{array}$ & 5 & $\begin{array}{l}\text { I. R\&D strategic management: understanding corporate strategies, conducting formal deliberation with se- } \\
\text { nior management, implementing exploration groups, identifying intellectual property, monitoring intellec- } \\
\text { tual property, involving employees in R\&D decision making } \\
\text { 2. R\&D quality awareness: providing employee awareness on quality issues, providing employee education on } \\
\text { quality issues, partnering with suppliers to identify needs/requirements } \\
\text { 3. R\&D client focus: reviewing conformance to clients' requirements, partnering with clients to identify needs/ } \\
\text { requirements, establishing trust with clients } \\
\text { 4. Research capability assessment: identifying/reviewing the strategic goals of R\&D, identifying/reviewing the } \\
\text { purpose of R\&D, implementing a R\&D process improvement team, having senior management evaluate } \\
\text { research projects, determining the competitive position of R\&D, documenting current practices, moni- } \\
\text { toring the transfer of employees, ex post evaluation of research } \\
\text { 5. R\&D process management: reviewing existing R\&D processes, implementing effective reporting practices }\end{array}$ \\
\hline & 6 & $\begin{array}{l}\text { I. Leadership: (i) amount of people who made initiatives; (ii) amount of ideas to be implemented per total } \\
\text { amount of ideas; (iii) contribution of a project to the sales increase objectives } \\
\text { 2. Strategic planning: (i) categorized amount of reasons for changes in a project; (ii) competence of project } \\
\text { personnel vs. competence areas needed in a project; (iii) project management assessment of the fulfill- } \\
\text { ment of the strategy in a project; (iv) assessment of resources and strategic competencies before and } \\
\text { after the project } \\
\text { 3. Customer and market focus: (i) ability of project personnel to enumerate the main markets and main cus- } \\
\text { tomers; (ii) contacts of project personnel and amount of visits to key customers' sales offices; (iii) exis- } \\
\text { tence of collected customer need document and its clarity and scope; (iv) number of project people who } \\
\text { know the specification and have the specification document; (v) systematic satisfaction measurements of } \\
\text { pilot customers; (vi) amount of recurred complaints; (vii) amount of realized customer requirements and } \\
\text { requests stated in advanced executed customer surveys; (viii) number of features based on fulfillment of } \\
\text { customer requirements; (ix) number of present customers who change to the product of project and } \\
\text { the speed of change } \\
\text { 4. Information and analysis: (i) availability of measurement information for project personnel; (ii) schedule } \\
\text { objectives and schedule keeping in different phases of a project; (iii) development of project lead time in } \\
\text { similar types of projects; (iv) quality and amount index of communication; (v) amount of problems/faults; } \\
\text { prioritized most difficult problem areas } \\
\text { 5. Human resource focus: (i) amount of initiatives per person; (ii) number of days in further education; (iii) } \\
\text { development speed and level of a project team } \\
\text { 6. Process management: (i) schedule keeping in a product process; (ii) amount of problems in planning and } \\
\text { support systems per day per user; (iii) number of initiatives from subcontractors }\end{array}$ \\
\hline $\begin{array}{l}\text { Prajogo } \\
\text { and Sohal } \\
\text { (2006); } \\
\text { Prajogo } \\
\text { and Hong } \\
\text { (2008) }\end{array}$ & 6 & $\begin{array}{l}\text { I. Leadership: share familiar beliefs, encourage improvement and learning, opportunity to share, a high degree } \\
\text { of unity of purpose } \\
\text { 2. Strategic planning: a mission statement has been communicated, a comprehensive and structured planning } \\
\text { process, the needs of all stakeholders are considered, the statement of strategy is agreed by senior } \\
\text { manager } \\
\text { 3. Customer focus: identify customers' needs and expectations, disseminating customer needs throughout } \\
\text { the firm, involve customers in our product design processes, maintain a close relationship with our cus- } \\
\text { tomers, effective process for resolving customers' complaints, regularly measure customer satisfaction } \\
\text { 4. Information and analysis: effective performance measurement system, up-to-date data and information is } \\
\text { readily available, regularly review company's performance, engaged in an active competitive benchmarking } \\
\text { 5. People management: training and development process, top-down and bottom-up communication process, } \\
\text { employee satisfaction is regularly measured, employee flexibility and multi-skilling, quality work environ- } \\
\text { ment }\end{array}$ \\
\hline
\end{tabular}

Table 2:TQM factors for the R\&D proposed in literature.

ISSN: 07 I8-2724. (http://www.jotmi.org)

Journal of Technology Management \& Innovation (c) Universidad Alberto Hurtado, Facultad de Economía y Negocios. 


\section{Method}

This is a multicase study, based on the analysis performed in eleven R\&D-based companies, operating in different Italian industries. The selection of the companies was intentional and sought cases in which, at least theoretically, R\&D could be viewed as essential, and in which TQM was implemented. This decision moved from the assumption that the goal of our paper, that is a qualitative research, was not a generalization in the statistical sense (Merriam, 1998). Each company was represented by the R\&D manager and/or employees belonging to the R\&D business unit, and sometimes by a founding partner of the company. Data collection was performed by means of individually performed open interviews, using a semi-structured script, which were recorded and later transcribed. The questions sought to identify observable features that could characterize the company's vision on R\&D, TQM implementation, and its impact in terms of performance. In order to obtain the interview instrument, starting from the results of the literature review, two Delphi round were conducted involving the R\&D managers of the same companies (Linstone and Turoff, 1975). Specifically, all the factors identified in the previous section have been proposed to a panel of expert set up to validate them. The panel was composed by 15 people, according the panel's size required by the Delphi technique, including 4 academics whose main research interest refer to R\&D and TQM, and I I managers of as companies. The task of the academics was to support the panel of experts during the decision making process, while managers covering a wide range of activities represented a heterogeneous sample of R\&D based companies. On the basis of findings from the literature, the academics proposed a set of factors structured into an appropriate questionnaire which was submitted to panel members. Hence, a two-round Delphi was carried out to refine the proposed factors: in the first round, the panel members were asked to express their agreement against each factor, as well as to judge the suitability of their implementation in the case of their R\&D unit. Moreover, panellists were also asked to indicate the need for further specifications of factors, as well as the main strengths and weaknesses of each factor. The results of the first round of Delphi led to several modifications to the original list of factor, hence, the original questionnaire was modified and resubmitted to the panel members during the second round of Delphi. Again, panellists were asked to operate as during the first round. A general agreement was reached at the end of the second round. As a result, some main issues were taken into account, as displayed in the following Table 3 (next page).

As for the performance, to measure the impact of TQM practices on various levels of improvement, this study incorporates different dimensions of performance: the financial, the product quality related and the product innovation related ones. As for the financial performance, previous studies have measured this construct in a number of ways (among others, Chan 2009a, 2009b; Ting and Lean, 2009; Bigliardi, 2013). In this study, following the study by Bigliardi (20I3), financial performance was measured comparing firm's performance (such as ROI, productivity, market share, and so on) to the same performance of main competitors. Conversely, in order to measure a company's performance related to quality and product innovation, we followed the work by Prajogo and Hong (2008), thus considering th $\mathrm{e}$ issues listed in Table 4.

A range of questions, including some open-ended questions, were presented in direct interviews conducted from May to July 2014 at the companies' sites. Interviewees were also asked to assess, on a scale from I to 5 (where I = "strongly disagree" and $5=$ "strongly agree") whether they agreed with the statements proposed pertaining to TQM.As for the performance, a similar 5-points scale was adopted, and interviewees were asked to compare the positioning of their company with respect to the main competitors (in this case, $\mathrm{I}=$ "much worse than competitors" and $5=$ "much better than competitors").

The analysis of the collected data followed the preliminary content examination method, supported by the analysis of respondents' verbal communications. This phase aimed at identifying whether observable aspects exist within each organization investigated and the importance given to every aspect by the actors interviewed.

\section{Sample}

The eleven companies investigated are all operating in the Italian landscape, even if belonging to different industries. Their descriptive characteristics are summarized in Table 5 . In order to preserve anonymity, the companies are referred to with Company A, Company B, ... Company K.

\section{Findings}

Top management at all the companies investigated stressed that their companies embrace the concept of TQM, while all except only some of them incorporate the concept of quality in R\&D wherever they can. At the beginning of the interviews, we tried to gather information about the meaning of TQM for the companies investigated, as well as to investigate their mindset with respect to TQM. The managers provided different definition of TQM. To quote manager of Company F, for example, "TQM is an overall philosophy aiming at meeting (or exceeding) the needs of the customers, both internal and external". Similarly, manager of Company $\mathrm{K}$ defined TQM as "A management philosophy aimed at the continuous improvement in all functions of an or- 


\begin{tabular}{|c|c|c|}
\hline Issues investigated (factors) & & Main observable aspects (practices) \\
\hline R\&D STRATEGY & $\square$ & $\begin{array}{l}\text { Understanding corporate strategies } \\
\text { Identifying the strategic goal of R\&D } \\
\text { A high degree of unity of purpose } \\
\text { Implementing exploration groups } \\
\text { Monitoring intellectual property } \\
\text { The needs of all stakeholders are considered }\end{array}$ \\
\hline $\begin{array}{l}\text { R\&D PROCESS } \\
\text { AND ANALYSIS }\end{array}$ & $\square$ & $\begin{array}{l}\text { Up-to-date data and information is readily available } \\
\text { Reviewing existing R\&D processes } \\
\text { Implementing effective reporting practices } \\
\text { "Fool-proof" (preventive-oriented) process design }\end{array}$ \\
\hline PRODUCT QUALITY & $\square$ & $\begin{array}{l}\text { Partnering with suppliers to identify needs requirements } \\
\text { Providing employees awareness on quality issues } \\
\text { Quality work environment }\end{array}$ \\
\hline CUSTOMER FOCUS & $\bar{\square}$ & $\begin{array}{l}\text { Identify customers' needs and expectations } \\
\text { Involve customers in our product design processes } \\
\text { Maintain a close relationship with our customers } \\
\text { Regularly measure customer satisfaction }\end{array}$ \\
\hline EMPOWERMENT & $\square$ & $\begin{array}{l}\text { Training and development process } \\
\text { Providing employees education on quality issues } \\
\text { Involving employees in R\&D decision making } \\
\text { Employee satisfaction is regularly measured } \\
\text { Employee flexibility and multi-skilling }\end{array}$ \\
\hline
\end{tabular}

Table 3: Main TQM and R\&D issues investigated. (Source: Prepared by the authors.)

\begin{tabular}{|l|rl|}
\hline \multicolumn{1}{|c|}{ PERFORMANCE } & \multicolumn{1}{|c|}{ Main observable aspects } \\
\hline FINANCIAL PERFORMANCE & $\square$ & ROI \\
& $\square$ & Productivity \\
& $\square$ & Market share \\
& $\square$ & Sales growth \\
& $\square$ & Operating costs \\
& $\square$ & ROA \\
\hline QUALITY PERFORMANCE & $\square$ & Performance of products \\
& $\square$ & Conformance to specifications \\
& $\square$ & Reliability \\
PERFORMANCE & $\square$ & Durability \\
\hline PRODUCT INNOVATION & $\square$ & Novelty \\
& $\square$ & Use of latest technologies \\
& $\square$ & Speed of product development \\
& $\square$ & Number of new products \\
& $\square$ & Early market entrants \\
\hline
\end{tabular}

Table 4: Main performance issues investigated. (Source: Prepared by the authors.)

ISSN: 07 I8-2724. (http://www.jotmi.org)

Journal of Technology Management \& Innovation (c) Universidad Alberto Hurtado, Facultad de Economía y Negocios. 
ganization to deliver services in line with customer's needs or requirements".

Almost all the people interviewed agreed in stating that a fundamental prerequisite for an effective implementation of TQM, in general but particularly within R\&D, is the creation of an organizational culture in which everyone, and at every stage of innovation process as well as every level of management, is committed to quality. A second prerequisite that was stated by managers of Company $E$ and Company $B$ is that "everyone, at every level, has to clearly understand the strategic importance of TQM".

Another important element that emerged in the first phase of the interviews refers to the main limitation in implementing TQM in R\&D. In particular, Company A and Company G clearly stressed that TQM application in their companies is in its infancy (they only recently applied some key concepts of TQM within their R\&D labs). The main limitation faced up by Company $A$ was due to language and philosophical barriers. Quoting its manager, "TQM was rejected by R\&D employees more than any other employees. The main critical factor is the willingness to maintain creativity and innovation, as well as the environmental conditions that prevail in the field". In Company G, the main limitation referred to the lack of results and lack of measurements in R\&D in the TQM sense. Moreover, the R\&D generally has a lack of focus on the customer.

In the second part of interviews, respondents were asked to answer to a series of questions dealing with the TQM factors and practices identified as a result of the literature review and of the two Delphi rounds (see previous Table 3 and Table 4). The responses to this set of questions are present- ed in Tables $6-10$, where the meaning response ratings on the 5-point scale are presented. The factor "R\&D strategy" (Table 6) includes six TQM practices that help the organization to identify possible future markets and new long-term strategies. Our results show that the majority of the companies involved in the research didn't pays greater attention to such construct. Companies E, B, F and J implemented almost all these practices, as demonstrated by the higher means obtained in such construct. Conversely, Company $\mathrm{C}$ and Company $A$ presented the lower mean ratings on "R\&D strategy". Table 6 also indicates which practices were considered more (or the less) important in the implementation of the TQM in the R\&D environment: the most adopted are "Understanding corporate strategies" and "A high degree of unity of purpose", followed by "Monitoring intellectual property". On the contrary, "Implementing exploration groups" seemed to be not important for the sample of companies.

Within the group of variables "R\&D process and analysis", we identify four TQM practices aimed at the evaluation and the continuous improvement of the R\&D activities.As shown in Table 7, in the implementation of such practices firms I, B, $E$ and $F$ excel, while little attention is paid by firms $A$ and $G$ towards these practices. The main efforts are related to a careful process design (in order to become "fool-proof") and to the availability of continually updated information on which to rely on research and development activities, while reporting activities and the reviews of the R\&D processes are not commonly implemented.

In the adoption of the TQM paradigm one of the most important concept is undoubtedly "product quality". In our research such construct is composed of three items which highlight evident differences within firms. We observed (Ta-

\begin{tabular}{|l|c|l|c|c|c|}
\hline \multicolumn{1}{|c|}{ Company } & $\begin{array}{c}\text { Year of } \\
\text { establishment }\end{array}$ & \multicolumn{1}{|c|}{ Industry } & $\begin{array}{c}\text { Number of } \\
\text { employees }\end{array}$ & Turnover & $\begin{array}{c}\text { Level of investments in } \\
\text { R\&D (\% turnover) }\end{array}$ \\
\hline Company A & 1996 & Food machinery & 8 & $<2$ million $€$ & n.a. \\
\hline Company B & 1965 & Construction & 42 & $2 \div 10$ million $€$ & $5 \%$ \\
\hline Company C & 2004 & Pharmaceutical & 48 & $2 \div 10$ million $€$ & n.a. \\
\hline Company D & 2000 & Telecommunication & 7 & $<2$ million $€$ & $2 \%$ \\
\hline Company E & 1994 & Food machinery & 40 & $<2$ million $€$ & $3 \%$ \\
\hline Company F & 1976 & Mechanical & 143 & $10 \div 25$ million $€$ & $3 \%$ \\
\hline Company G & 1997 & Pharmaceutical & 146 & $<2$ million $€$ & $1 \%$ \\
\hline Company H & 1975 & Food & 38 & $2 \div 10$ million $€$ & $1 \%$ \\
\hline Company I & $199 I$ & Biotechnology & 47 & $2 \div 10$ million $€$ & $7 \%$ \\
\hline Company J & 1991 & Electronics & 29 & $2 \div 10$ million $€$ & n.a. \\
\hline Company K & 2007 & Automotive & 142 & $2 \div 10$ million $€$ & $6 \%$ \\
\hline
\end{tabular}

Table 5: General characteristics of the companies examined. (Source: Prepared by the authors.)

ISSN: 07I 8-2724. (http://www.jotmi.org) 
ble 8) that companies A, C and G are reluctant to adopt these TQM practices, while companies $\mathrm{B}, \mathrm{E} ; \mathrm{F}$ and $\mathrm{K}$ consider product quality as one of their sources of competitive advantage, recognizing its strategic importance for the market success of the firm. The role assumed by the suppliers seems crucial: almost all the firms stated that partnering activities with them are fundamental. Conversely, the creation of a quality work environment seemed to be still less considered in the R\&D based companies.

As far as the "customer focus", this group of TQM practices shows a high heterogeneity in the answers: there are firms like $E, F$ and $K$ which focused great attention to the customers, while others, like $\mathrm{D}, \mathrm{G}$ and $\mathrm{H}$, didn't recognized the strategic relevance of the customers (Table 9). In the definition of the TQM paradigm the role of customer is clearly highlighted, but only few firms seem able to implement such concept in an R\&D environment. In particular, it appeared to be difficult for companies to maintain a close relationship with their customers.

Finally, results reported in Table 10 show that also the empowerment of the personnel covers an important role in the TQM definition and even more in R\&D environments. In a total quality approach it's important to increase the accountability and the involvement of R\&D employees in the decision making process of the firm. In these practices firms like $F, B, I$ and $G$ excel, thus devoting great efforts in providing employees education on quality issues, in training and development, in measuring employees satisfaction, result- ing in a greater flexibility of their R\&D workforce. On the contrary, Company $\mathrm{H}$ and Company J appeared to be those where TQM practices related to empowerment are still in its infancy of application. As for the single practice, companies paid large attention to provide employees education on quality issues, while the measurement of their satisfaction stand on a secondary level.

In Table II the different answers given by the II firms in terms of performance are summarized. They are divided in three different perspectives: financial, quality and product innovation. For what concerns the first, we noted that the best financial results were achieved by firms $E, B$ and $F$, while firms like $A$ and $G$ were the worst from this point of view; in terms of products' quality firms $\mathrm{B}, \mathrm{E}, \mathrm{F}$ and $\mathrm{K}$ obtained very high values, demonstrating their great attention to the products they made. On the contrary, Company G seemed to ignore the relevance of such performance perspective in developing its products. Finally, considering the product innovation performance perspective, we observed the highest values in companies $F, E$ and $K$, while Company $D$ showed its limits in realizing innovative products.

From a cross-analysis of these tables, it appears that those companies that are characterized by an effective implementation of the TQM have reached higher performances (namely, companies E, F, B and K). On the contrary, lower results in terms of performances were obtained by companies $A$ and $G$, which stated their limited capabilities in the implementation of many of the TQM techniques discussed.

\begin{tabular}{|c|c|c|c|c|c|c|c|c|c|c|c|c|c|}
\hline \multirow[b]{2}{*}{ FACTOR } & \multirow[b]{2}{*}{ PRACTICES } & \multicolumn{11}{|c|}{ COMPANIES } & \multirow[b]{2}{*}{ MEANS } \\
\hline & & A & B & C & D & $\mathrm{E}$ & $\mathrm{F}$ & G & $\mathrm{H}$ & 1 & J & $\mathrm{K}$ & \\
\hline \multirow{7}{*}{ R\&D STRATEGY } & $\begin{array}{l}\text { Understanding cor- } \\
\text { porate strategies }\end{array}$ & 4 & 4 & 3 & 2 & 4 & 5 & 3 & 3 & 4 & 3 & 4 & 3,5 \\
\hline & $\begin{array}{l}\text { Identifying the strate- } \\
\text { gic goal of R\&D }\end{array}$ & 3 & 3 & 2 & 3 & 4 & 3 & 2 & 3 & 3 & 4 & 3 & 3,0 \\
\hline & $\begin{array}{l}\text { A high degree of } \\
\text { unity of purpose }\end{array}$ & 4 & 3 & 3 & 4 & 3 & 3 & 5 & 4 & 4 & 3 & 3 & 3,5 \\
\hline & $\begin{array}{l}\text { Implementing explo- } \\
\text { ration groups }\end{array}$ & 2 & 3 & 1 & 2 & 3 & 2 & 3 & 2 & I & 5 & 2 & 2,4 \\
\hline & $\begin{array}{l}\text { Monitoring intel- } \\
\text { lectual property }\end{array}$ & 2 & 4 & 3 & 2 & 5 & 3 & 2 & 4 & 5 & 3 & 4 & 3,4 \\
\hline & $\begin{array}{l}\text { The needs of all } \\
\text { stakeholders are } \\
\text { considered }\end{array}$ & 1 & 3 & 3 & 2 & 4 & 4 & 3 & 3 & 2 & 2 & 3 & 2,7 \\
\hline & MEANS & 2,7 & 3,3 & 2,5 & 2,5 & 3,8 & 3,3 & 3,0 & 3,2 & 3,2 & 3,3 & 3,2 & \\
\hline
\end{tabular}

Table 6: Mean response ratings to "R\&D strategy" construct.

ISSN: 07I 8-2724. (http://www.jotmi.org) 


\begin{tabular}{|c|c|c|c|c|c|c|c|c|c|c|c|c|c|}
\hline \multirow[b]{2}{*}{ FACTOR } & \multirow[b]{2}{*}{ PRACTICES } & \multicolumn{11}{|c|}{ COMPANIES } & \multirow[b]{2}{*}{ MEANS } \\
\hline & & A & B & C & $\mathrm{D}$ & $E$ & $\mathrm{~F}$ & G & $\mathrm{H}$ & 1 & J & $\mathrm{K}$ & \\
\hline \multirow{5}{*}{$\begin{array}{l}\text { R\&D PROCESS } \\
\text { AND ANALYSIS }\end{array}$} & $\begin{array}{l}\text { Up-to-date data and } \\
\text { information is readily } \\
\text { available }\end{array}$ & 2 & 5 & 3 & 4 & 4 & 4 & 3 & 3 & 4 & 3 & 3 & 3,5 \\
\hline & $\begin{array}{l}\text { Reviewing existing } \\
\text { R\&D processes }\end{array}$ & 2 & 4 & 2 & 1 & 4 & 3 & 2 & 3 & 5 & 4 & 3 & 3,0 \\
\hline & $\begin{array}{l}\text { Implementing effecti- } \\
\text { ve reporting practices }\end{array}$ & 2 & 4 & 3 & 3 & 4 & 4 & 2 & 2 & 5 & 2 & 4 & 3,2 \\
\hline & $\begin{array}{l}\text { "Fool-proof" (pre- } \\
\text { ventive-oriented) } \\
\text { process design }\end{array}$ & 4 & 5 & 3 & 3 & 5 & 5 & 3 & 4 & 4 & 4 & 4 & 4,0 \\
\hline & MEANS & 2,5 & 4,5 & 2,8 & 2,8 & 4,3 & 4,0 & 2,5 & 3,0 & 4,5 & 3,3 & 3,5 & \\
\hline
\end{tabular}

Table 7: Mean response ratings to "R\&D process and analysis" construct.

\begin{tabular}{|c|c|c|c|c|c|c|c|c|c|c|c|c|c|}
\hline \multirow[b]{2}{*}{ FACTOR } & \multirow[b]{2}{*}{ PRACTICES } & \multicolumn{11}{|c|}{ COMPANIES } & \multirow[b]{2}{*}{ MEANS } \\
\hline & & A & B & C & D & $\mathrm{E}$ & $\mathrm{F}$ & $\mathrm{G}$ & $\mathrm{H}$ & 1 & J & $\mathrm{K}$ & \\
\hline \multirow{4}{*}{$\begin{array}{l}\text { PRODUCT QUA- } \\
\text { LITY }\end{array}$} & $\begin{array}{l}\text { Partnering with } \\
\text { suppliers to identify } \\
\text { needs requirements }\end{array}$ & 2 & 5 & 3 & 4 & 5 & 5 & 3 & 4 & 4 & 5 & 5 & 4,1 \\
\hline & $\begin{array}{l}\text { Providing employees } \\
\text { awareness on quality } \\
\text { issues }\end{array}$ & 3 & 4 & 4 & 4 & 5 & 4 & 3 & 3 & 4 & 3 & 5 & 3,8 \\
\hline & $\begin{array}{l}\text { Quality work environ- } \\
\text { ment }\end{array}$ & 4 & 5 & 2 & 3 & 4 & 4 & 2 & 3 & 2 & 4 & 4 & 3,4 \\
\hline & MEANS & 3,0 & 4,7 & 3,0 & 3,7 & 4,7 & 4,3 & 2,7 & 3,3 & 3,3 & 4,0 & 4,7 & \\
\hline
\end{tabular}

Table 8: Mean response ratings to "product quality" construct.

\begin{tabular}{|c|c|c|c|c|c|c|c|c|c|c|c|c|c|}
\hline \multirow[b]{2}{*}{ FACTOR } & \multirow[b]{2}{*}{ PRACTICES } & \multicolumn{11}{|c|}{ COMPANIES } & \multirow[b]{2}{*}{ MEANS } \\
\hline & & A & B & C & $\mathrm{D}$ & $\mathrm{E}$ & $\mathrm{F}$ & G & $\mathrm{H}$ & 1 & J & K & \\
\hline \multirow{5}{*}{$\begin{array}{c}\text { CUSTOMER FO- } \\
\text { CUS }\end{array}$} & $\begin{array}{l}\text { Identify customers' } \\
\text { needs and expecta- } \\
\text { tions }\end{array}$ & 4 & 4 & 3 & 2 & 5 & 5 & 2 & 2 & 2 & 4 & 5 & 3,5 \\
\hline & $\begin{array}{l}\text { Involve customers in } \\
\text { our product design } \\
\text { processes }\end{array}$ & 3 & 2 & 3 & 2 & 4 & 5 & 3 & 2 & 4 & 3 & 5 & 3,3 \\
\hline & $\begin{array}{l}\text { Maintain a close re- } \\
\text { lationship with our } \\
\text { customers }\end{array}$ & 4 & 3 & 3 & 3 & 5 & 4 & 2 & 3 & 1 & 2 & 4 & 3,1 \\
\hline & $\begin{array}{l}\text { Regularly measure } \\
\text { customer satisfaction }\end{array}$ & 4 & 2 & 3 & 2 & 5 & 5 & 2 & 2 & 3 & 3 & 4 & 3,2 \\
\hline & MEANS & 3,8 & 2,8 & 3,0 & 2,3 & 4,8 & 4,8 & 2,3 & 2,3 & 2,5 & 3,0 & 4,5 & \\
\hline
\end{tabular}

Table 9: Mean response ratings to "customer focus" construct.

ISSN: 07I 8-2724. (http://www.jotmi.org)

Journal of Technology Management \& Innovation (c) Universidad Alberto Hurtado, Facultad de Economía y Negocios. 


\begin{tabular}{|c|c|c|c|c|c|c|c|c|c|c|c|c|c|}
\hline \multirow[b]{2}{*}{ FACTOR } & \multirow{2}{*}{ PRACTICES } & \multicolumn{11}{|c|}{ COMPANIES } & \multirow[b]{2}{*}{ MEANS } \\
\hline & & A & B & C & D & $\mathrm{E}$ & $\mathrm{F}$ & G & $\mathrm{H}$ & 1 & J & K & \\
\hline \multirow{6}{*}{ EMPOWERMENT } & $\begin{array}{l}\text { Training and develop- } \\
\text { ment process }\end{array}$ & 3 & 4 & 2 & 4 & 3 & 4 & 4 & 2 & 4 & 3 & 3 & 3,3 \\
\hline & $\begin{array}{l}\text { Providing employees } \\
\text { education on quality } \\
\text { issues }\end{array}$ & 4 & 5 & 2 & 4 & 4 & 5 & 4 & 2 & 4 & 4 & 2 & 3,6 \\
\hline & $\begin{array}{l}\text { Involving employees in } \\
\text { R\&D decision making }\end{array}$ & 2 & 4 & 3 & 4 & 3 & 4 & 5 & 2 & 5 & 2 & 4 & 3,5 \\
\hline & $\begin{array}{l}\text { Employees satisfaction } \\
\text { is regularly measured }\end{array}$ & I & 3 & 3 & 4 & 4 & 4 & 3 & 3 & 4 & I & 3 & 3,0 \\
\hline & $\begin{array}{l}\text { Employees flexibility } \\
\text { and multi-skilling }\end{array}$ & 4 & 5 & 4 & 3 & 5 & 5 & 4 & 3 & 4 & 3 & 5 & 4,1 \\
\hline & MEANS & 2,8 & 4,2 & 2,8 & 3,8 & 3,8 & 4,4 & 4,0 & 2,4 & 4,2 & 2,6 & 3,4 & \\
\hline
\end{tabular}

Table 10: Mean response ratings to "empowerment" construct.

\begin{tabular}{|c|c|c|c|c|c|c|c|c|c|c|c|c|c|}
\hline \multirow[b]{2}{*}{ CONSTRUCTS } & \multirow[b]{2}{*}{ ITEMS } & \multicolumn{11}{|c|}{ COMPANIES } & \multirow[b]{2}{*}{ MEANS } \\
\hline & & A & B & C & D & $E$ & $\mathrm{~F}$ & G & $\mathrm{H}$ & 1 & J & $\mathrm{K}$ & \\
\hline \multirow{7}{*}{$\begin{array}{l}\text { FINANCIAL PER- } \\
\text { FORMANCE }\end{array}$} & ROI & 2 & 3 & 2 & 2 & 4 & 5 & 3 & 1 & 2 & 5 & 4 & 3,0 \\
\hline & Productivity & 2 & 4 & 3 & 2 & 4 & 3 & 2 & 4 & 5 & 3 & 4 & 3,3 \\
\hline & Market share & 1 & 3 & 3 & 2 & 4 & 4 & 2 & 3 & 2 & 2 & 4 & 2,7 \\
\hline & Sales growth & 2 & 5 & 3 & 4 & 4 & 5 & 1 & 3 & 4 & 3 & 3 & 3,4 \\
\hline & Operating costs & 2 & 4 & 2 & I & 5 & 3 & 2 & 3 & 5 & 4 & 3 & 3,1 \\
\hline & ROA & 2 & 4 & 2 & 3 & 4 & 4 & 2 & 2 & 5 & 2 & 4 & 3,1 \\
\hline & MEANS & 1,8 & 3,8 & 2,5 & 2,3 & 4,2 & 4,0 & 2,0 & 2,7 & 3,8 & 3,2 & 3,7 & \\
\hline \multirow{5}{*}{$\begin{array}{l}\text { QUALITY PERFOR- } \\
\text { MANCE }\end{array}$} & $\begin{array}{l}\text { Performance of pro- } \\
\text { ducts }\end{array}$ & 4 & 5 & 4 & 3 & 5 & 5 & 3 & 4 & 4 & 4 & 4 & 4,1 \\
\hline & $\begin{array}{l}\text { Conformance to speci- } \\
\text { fications }\end{array}$ & 2 & 5 & 3 & 4 & 5 & 5 & 3 & 4 & 3 & 5 & 5 & 4,0 \\
\hline & Reliability & 3 & 4 & 4 & 4 & 5 & 4 & 3 & 3 & 4 & 3 & 5 & 3,8 \\
\hline & Durability & 3 & 5 & 2 & 3 & 4 & 4 & 2 & 3 & 2 & 4 & 4 & 3,3 \\
\hline & MEANS & 3,0 & 4,8 & 3,3 & 3,5 & 4,8 & 4,5 & 2,8 & 3,5 & 3,3 & 4,0 & 4,5 & \\
\hline \multirow{6}{*}{$\begin{array}{c}\text { PRODUCT INNO- } \\
\text { VATION PERFOR- } \\
\text { MANCE }\end{array}$} & Novelty & 2 & 4 & 3 & 2 & 4 & 5 & 2 & 2 & 2 & 4 & 4 & 3,1 \\
\hline & $\begin{array}{l}\text { Use of latest techno- } \\
\text { logies }\end{array}$ & 3 & 3 & 3 & 2 & 4 & 5 & 3 & 2 & 4 & 3 & 4 & 3,3 \\
\hline & $\begin{array}{l}\text { Speed of product de- } \\
\text { velopment }\end{array}$ & 2 & 4 & 4 & 3 & 4 & 4 & 2 & 3 & 1 & 2 & 4 & 3,0 \\
\hline & $\begin{array}{l}\text { Number of new pro- } \\
\text { ducts }\end{array}$ & 4 & 2 & 3 & 2 & 5 & 5 & 2 & 2 & 3 & 3 & 4 & 3,2 \\
\hline & Early market entrants & 1 & 3 & 1 & 2 & 4 & 5 & 3 & 3 & 2 & 2 & 3 & 2,6 \\
\hline & MEANS & 2,4 & 3,2 & 2,8 & 2,2 & 4,2 & 4,8 & 2,4 & 2,4 & 2,4 & 2,8 & 3,8 & \\
\hline
\end{tabular}

Table II: Mean response ratings to "performance" constructs.

ISSN: 07I 8-2724. (http://www.jotmi.org)

Journal of Technology Management \& Innovation (c) Universidad Alberto Hurtado, Facultad de Economía y Negocios. 


\section{Discussions and future research}

Two main research questions were at the basis of our research:

I) Does the implementation of TQM practices in R\&D environments affect the business performance?

2) Which TQM practices in R\&D environments are critical for an effective implementation of this approach?

In order to answer to these research questions, the data for this study was drawn from a multicase study of R\&D based companies operating in different Italian industries and implementing TQM practices. First, it emerged that there are several definitions of TQM, but the essence of these definitions share many common elements: the customer is at the center of attention and represents a driving force in the TQM philosophy, management commitment is an essential component for TQM to be successful, and lastly, cultural and organizational changes are necessary conditions for TQM success.

Second, it emerged a heterogeneous adoption of the TQM practices in the R\&D environment among the eleven firms analyzed. Some firms (namely E and F) excel in all the TQM perspectives investigated, obtaining the highest values in almost all the evaluations, others regularly implement the TQM prescriptions, in order to increase their quality and competitiveness, and finally some firms are not able to adopt such practices in an effective way. The same obtained the lowest values in almost all the constructs analyzed. These differences in terms of level of adoption of TQM practices seem to be correlated with the performance analyzed: specifically, our results support the hypothesis proposed as the first research question that an adequate implementation of such practices lead to higher performance.

Third, as answer to the second research question, a deepen analysis of the quantitative results and the qualitative answers provided by the R\&D managers of the firms involved in the study led to suppose a different relative importance of each constructs. In order to understand such differences, we tried to combine what emerged from both these perspectives: we noted that three of the four best firms in terms of overall performances ( $E, F$ and $K$ ) showed significant high values, at the same time, in two fundamental constructs: "product quality" and "customer focus". In addition, there are also the statements of the R\&D managers of companies $\mathrm{K}$ and $\mathrm{F}$ hinting a possible explanation of this phenomenon: "The implementation of the TQM approach in the R\&D function, heavily focused on product quality, is very difficult. A successful implementation of the TQM in such scientific environment can be achieved only through the effective balance between two different (and often with conflicting goals) perspectives: the customer focus and the product quality."

Thus, our research emphasizes the ability to achieve a tradeoff between these different perspectives: a firm needs to control, on the one hand, the customer needs and expectations, and on the other hand the quality of its products in order to obtain better performances and then to gain competitive advantage.

We recognize some limitations as well, mainly due to the methodology adopted. Case study methodology in fact does

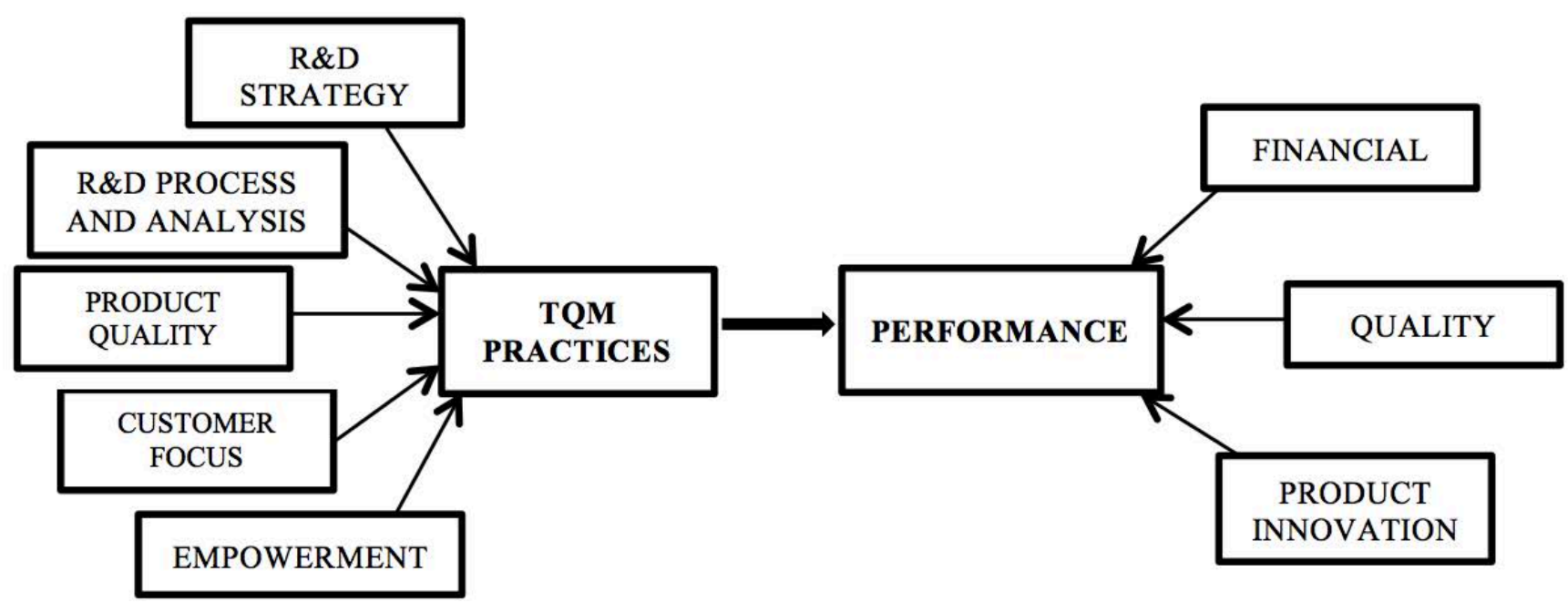

Figure I:The conceptual model resulted.

ISSN: 07 I8-2724. (http://www.jotmi.org)

Journal of Technology Management \& Innovation (c) Universidad Alberto Hurtado, Facultad de Economía y Negocios. 
not allow a generalization of the results obtained, but shed light on the issue investigated (the adoption of TQM in R\&D in this case). The research adopts a case-study approach and conducts cross-case comparative analyses in order to develop insights into the implementation of TQM practices within R\&D environments. Even if the sample heterogeneity allows widens coverage and the perspective, a more numerous sample of companies would allow a generalization of the results obtained.

The study presents both managerial and theoretical implications.As for the former, findings seem to suggest to managers of R\&D based companies that the implementation of TQM practices may allow companies to better perform in terms of customer satisfaction and product quality, with respect to companies that do not implement the same practices. Moreover, results suggest that a trade-off between customer focus and product quality may help companies in obtaining better performance. As far as the theoretical implications are concerned, based on the results previously described, the conceptual model depicted in Figure I (prev. page) can be easily derived. Future research would be aimed at validating such a model within a larger sample of companies by performing a statistical survey.

\section{References}

AGUS, A., Hassan, Z. (2000). Exploring the Relationship between the Length of Total Quality Management Adoption and Financial Performance: An Empirical Study in Malaysia. Production and Inventory Management Journal, First Quarter, 37, 18-23.

AHIRE, S.L., Landeros, R., Golhar, D. (1995) Total quality management: A literature review and an agenda for future research. Production and Operations Management, 277-307.

BIGLIARDI, B. (20I3). The effect of innovation on financial performance: A research study involving SMEs. Innovation: Management, Policy \& Practice, 15 (2), 245-256.

BRAH, S.A., Lee, S.L., Rao, B.M. (2002). Relationship between TQM and Performance of Singapore Companies. International Journal of Quality \& Reliability Management, 19 (4), 356-379.

CHAN, K.H. (2009a). Impact of intellectual capital on organizational performance. An empirical study of companies in the Hang Seng Index (Part I). The Learning Organization, $16(I), 4-2 I$.

CHAN, K.H. (2009b). Impact of intellectual capital on organizational performance. An empirical study of companies in the Hang Seng Index (Part 2). The Learning Organization, $16(1), 22-39$.

CHANG, P.-L., Hsu, C.-W. (1998). A quality management model for research institutes responsible for governmentsupported R\&D projects. International Journal of Technology Management, Vol. 16, 4/5/6, 393-404.

CHATTERJI, D., Davidson, J.M. (200I). Examining TQM's legacies for R\&D. Research Technology Management, 44 (I), I012.

DEMING, W.E. (1986). Out Of the Crisis: MIT Center for Advanced Engineering. Cambridge University Press.

EASTON, G.S., Jarrell, S.L. (1994). The Effect of Total Quality Management on Corporate Performance, An Empirical Investigation. Indiana University, Bloomington, Indiana, USA.

FENG, M., Terziovski, M., Samson, D. (2008). Relationship of ISO 900I:2000 Quality System Certification with Operational and Business Performance. Journal of Manufacturing Technology Management, 19(I), 22-37. 
FLYYN, B.B., Schroder, R.G., Sakakibara, S. (1994). A Framework for Quality Management Research and an Associated Measurement Instrument. Journal of Operations Management, I I, 339-366.

FOTOPOULOS, C.B., Psomas, E.L. (2009). The Impact of "Soft" and "Hard" TQM Elements on Quality Management Results. International Journal of Quality \& Reliability Management, 26(2), I50-163.

FRYER, Karen J., Antony, J., Douglas, A. (2007). Critical Success Factors of Continuous Improvement in the Public Sector.The TQM Magazine, 19(5), 497-5I7.

GADENNE, D., Sharma, B. (2002). An Inter-Industry Comparison of Quality Management Practices and Performance. Managing Service Quality, 12(6), 394-404.

HASSAN, M., Muklitar, A., Qureshi, U.S., Sharif, S. (20I2). Impact of TQM Practices on Firm's Performance of Pakistan's Manufacturing Organizations. International Journal of Academic Research in Business and Social Sciences, 2 (I0).

KAPLAN, H.C., Brady, P.W., Dritz, M.C., Hooper, D.K., Linam, W.M., Froehle, C.M., Et Al. (20I0). The Influence of Context on Quality Improvement Success in Health Care:A Systematic Review of the Literature. The Milbank Quarterly, 88(4), 500-559.

KARUPPUSAMI, G., Gandhinathan, R. (2006) Pareto analysis of critical success factors of total quality management: A literature review and analysis. The TQM Magazine, I8 (4), 372-385.

KAYNAK, H. (2003). The Relationship between Total Quality Management Practices and their Effects on Firm Performance. Journal of Operations Management, 2I, 405-435.

KIELLA, M.L., Golhar, D.Y. (1997). Total quality management in R\&D environment. International Journal of Operation and Production Management, 17(2), 184-198.

KINSEY, A.C., Pomeroy, W.B., Martin, C.E., Gebhard, P.H. (1953). Sexual behavior in the human female.W.B. Saunders, New York.

KUMAR, V., Choisne, F., Grosbois, D.D., Kumar, U. (2009). Impact of TQM On Company's Performance. International Journal of Quality \& Reliability Management, 26(I), 23-37.

KUMAR, V., Boyle, T. (200I). A quality management framework for manufacturing-based R\&D environment. International Journal of Quality \& Reliability Management, I8(3), 336-359.
LAGROSEN, S., Lagrosen, Y. (2003). Management of service quality-differences in values, practices and outcomes. Managing Service Quality. 13 (5), 370-38I.

LEE, S.M., Rho, B.H., Lee, S.G. (2003). Impact of Malcolm Baldrige National Quality Award criteria on organizational quality performance. International Journal of Production Research. 4I (9), 2003-2020.

LINSTONE, H.A., Turoff, M. (1975). Introduction. In H.A. Linstone, M. Turoff (Eds.). The Delphi method: Techniques and applications (pp. 3-12). Reading, MA: Addison-Wesley Publishing Company.

LU, E., Sohal, A. (1993). Success factors, weaknesses and myths concerning TQM implementation in Australia. Total Quality Management, 4(3), 245-256.

MACINATI, S.M. (2008). The Relationship between Quality Management Systems and Organizational Performance in the Italian National Health Service. Elsevier Ireland Ltd, 85(7), 228-24I.

MALIK, M.N., Khan, H.H. (20II). Total Quality Management in Manufacturing Industry of Pakistan:A Case of Cement Industry. Paper Presented at the International Conference on Trends in Mechanical and Industrial Engineering.

MERRIAM, S.B. (1998). Qualitative research and case study applications in education. San Francisco: Jossey-Bass.

OJANEN, V., Piippo, P., Tuominen, M., (2002). Applying quality award criteria in R\&D project assessment. International Journal of Production Economics 80 (I), I 19-1 28.

PATINO, H. (1997). Applying total quality to R\&D at Coors Brewing Company. Research \&Technology Management, 40 (5), 32-37.

PEARSON, A.W., Vaughan, N., Butler, J., (1998). The implementation of TQM in R\&D. International Journal of Technology Management 16 (4-6), 405-432.

PETRONI, G., Dormio, A. I., Nosella, A., Verbano, C. (2003). The TQM trajectories in research and development: two Italian cases. European Journal of Innovation Management, 6(4), 239-252.

PLONSKY, M. (2004). Psychology with style: A hypertext writing guide (Version 5) http://www.uwsp.edu/psych/apa4b. htm [Accessed 19 October, 2013]. 
POWELL, T.C. (1995). Total Quality Management as Competitive Advantage: A Review and Empirical Study. Strategic Management Journal, I6(I), 15-37.

PRAJOGO, D.I., Hong, S.W. (2008). The effect of TQM on performance in $R$ \& $D$ environment: a perspective from South Korean firms. Technovation, 28, 855-863.

PRAJOGO, D.I. (2005). The Comparative Analysis of TQM Practices and Quality Performance between Manufacturing and Service Firms. International Journal of Service Industry Management, 16(3), 217-228.

PRAJOGO, D.I., Sohal,A.S. (2003).The Relationship between TQM Practices, Quality Performance, and Innovation Performance. International Journal of Quality \& Reliability Management, 20(8), 90I-918.

RAHMAN, S.U. (200I). A Comparative Study of TQM Practice and Organizational Performance of Smes With And Without ISO 9000 Certification. International Journal of Quality \& Reliability Management, 18(I), 35-49.

RILEY, E.P., Lochry, E.A., Shapiro, N.R. (1979). Lack of response inhibition in rats prenatally exposed to alcohol. Psychopharmacology, 62, 47-52.

SAMSON, D., Terziovski, M., (1999). The relationship between total quality management practices and operational performance. Journal of Operations Management 17 (4), 393-409.

SARAPH, J.V., Benson, P.G., Schroeder, R.G. (1989).An Instrument for Measuring the Critical Factors of Quality Management. Decision Sciences, 20(4), 810-829.

SHARMA, B. (2006). Quality Management Dimensions, Contextual Factors, and Performance:An Empirical Investigation. Total Quality Management and Business Excellence, 17(9) |23|-| 244.

SHARMA, M., Kodali, R. (2008). TQM implementation elements for manufacturing excellence. The TQM Journal, 20(6), 599-621.

SHARMAN, G.K. (1996). TQM and R\&D: an overview. The TQM Magazine, 8 (2), I I-I6.

SILA, I., Ebrahimpour, M. (2002). An investigation of the total quality management survey based research published between 1989 and 2000:A literature review. International Journal of Quality and Reliability Management. 19(7), 902-970.
SILA, I. (2005). The Influence of Contextual Variables on TQM Practices and TQM-Organizational Performance Relationships. The Business Review, Cambridge, 4, 204-209.

SILA, I. (2007). Examining the Effects of Contextual Factors on TQM and Performance Through the Lens of Organizational Theories: An Empirical Study. Journal of Operations Management, 83-109.

STERMAN, J.D., Repenning, N.P., Kofman, F. (1997). Unanticipated Side Effects of Successful Quality Program; Exploring a Paradox of Organizational Improvement. Management Science, 43, 503-52I.

TADESSE, F, Osada, H. (2010). Context of TQM Application for NPD in Developing Countries: an Empirical Study on Deming Prize Winners from India and Thailand, Portland International Center for Management of Engineering and Technology, Thailand, I647-I654.

TALAVERA, G.V. (2004).TQM Constructs Development and Validation:The Philippine Experience. Gadja Mada International Journal of Business, 6(3).

TARI, J..., Molina, F.J., Castejon, L.J. (2006). The Relationship between Quality Management Practices and Their Effects on Quality Outcomes. European Journal of Operational Research, 483-50I.

TAYLOR, R., Pearson, A.W. (1994). Total quality management in research and development. TQM Magazine 6 (I), 26-34.

TENNER, A.R. (|99|), Quality management beyond manufacturing, Research \& Technology Management, 34 (5), 27-32.

TERZIOVSKI, M., Samson, D. (1999). The Link between Total Quality Management Practice and Organizational Performance. International Journal of Quality \& Reliability Management, 16(3), 226-237.

TING, I.W.K., Lean, H.H. (2009). Intellectual capital performance of financial institutions in Malaysia. Journal of Intellectual capital, I0(4), 588-599.

WALI, Deshmukh, Gupta. (2003). Critical Success Factors of TQM: A Select Study of Indian Organizations. Production Planning \& Control, I4(I), 3-14.

ZEHIR, C., Ertosunb, Ö.G., Zehir, S., Müceldilli, B. (2012). Total Quality Management Practices' Effects on Quality Performance and Innovative Performance. Social and Behavioral Sciences, 4I, 273-280. 